\title{
The Quest for quies mentis
}

\author{
Hilary Powell
}

\begin{abstract}
This chapter explores the relationship between mental rest and wandering thoughts as conceived in the literature of the early medieval monastic tradition. As with contemporary neuroscientific models, medieval theologians were aware of the mind's natural propensity to roam and drift away from a task toward unrelated thoughts and feelings. While universal and unavoidable, this was nonetheless unacceptable, and monks were instructed to make every effort to still wandering thoughts. For the monks, therefore, mental rest involved unceasing vigilance and mental exertion, for it was a task which, if neglected, could lead to spiritual destitution.
\end{abstract}

Keywords Cassian - Medieval · Mind wandering - Monasticism - Quiet mind

Acquiring a still or restful mind lay at the core of the medieval Christian monastic tradition and, according to St. Anselm, the great theologian of the eleventh century, it was the goal towards which every monk ought to be oriented. In a letter written in the early 1070s, Anselm advised Lanzo,

\footnotetext{
H. Powell $(\bowtie)$

Durham University, Durham, United Kingdom

e-mail: hilary.powell@durham.ac.uk

(C) The Author(s) 2016

F. Callard et al. (eds.), The Restless Compendium, DOI 10.1007/978-3-319-45264-7_3
} 
a novice monk at Cluny, to avoid 'a restless mind ("mentis inquietudine") ... [and] devote your whole strength to attaining a "quieti mentis". ${ }^{1}$ Like most medieval epistles, Anselm's letter reached a much larger audience than just Lanzo: not only read aloud to the entire Cluny community, it was also copied and circulated throughout the Benedictine order and even incorporated by his hagiographer into his saint's life. ${ }^{2}$ The subject of restless minds ranked high on the medieval monastic agenda.

Some 900 years later, restless minds have once again garnered interest, not among theologians this time, but in the field of cognitive neuroscience. In their 2006 article entitled 'The Restless Mind', neuroscientists Jonathan Smallwood and Jonathan Schooler characterized mind wandering as 'one of the most ubiquitous and pervasive of all cognitive phenomena'. ${ }^{3}$ The feeling of our minds drifting away from a task towards unrelated inner thoughts, fantasies and imaginings is now a feasible object of scientific enquiry. Recent neuroimaging research reveals a significant overlap between brain regions activated during episodes of mind wandering and the large-scale neural network known as the default mode network (DMN). ${ }^{4}$ i Scans conducted during the so-called 'resting state', when the mind is not occupied with an explicit task, show the brain busily engaged in mental processes typical of mind wandering. In other words, the mind taking a rest from mental tasks does not rest in an idle or inert sense but remains active - roaming, wandering and inhabiting daydreams. This complex nexus of rest, unrest, mental wandering, work and attention is fascinating, and suggests an interesting lens through which we might review the medieval standpoint. Moreover, what might be the recursive effects of such an undertaking, or how might early medieval notions of mental rest and mind wandering interrogate the experimental paradigms of the cognitive sciences?

The word 'rest' derives from the Old English rest (noun) or restan (verb) and is Germanic in origin, relating to a break in activity. In Latin, the closest equivalent is requies, 'rest from labour', which has its root in quies. Quies defies a straightforward translation since it was used as both a measure of stillness and silence. It encompassed ideas of 'rest, quiet, repose, the cessation of labour, the leading of a quiet life and keeping still' ${ }^{5}$ ii Rather than supposing the word possessed a definite meaning, we might be better off envisaging it as a concept. This is certainly how the

\footnotetext{
${ }^{i}$ See Chap. 2.

ii Cf. Chap. 23.
} 
fourth- and fifth-century Christian monks living in the Egyptian desert interpreted it. A collection of sayings codifying the wisdom of the early Desert Fathers devoted an entire chapter to the subject of quies. ${ }^{6}$ It was a celebrated and attractive characteristic of desert dwelling; an early visitor wrote of the desert's 'huge silence and great quiet' ('silentium ingens, quies magna'). ${ }^{7}$ Yet quies was also a quality or emotional state to attain, as testified by Anselm's enjoinder that a 'quieti mentis' was something to which one should devote one's whole strength. Withdrawal to the desert/monastery - the foundational principle of monasticism, known as anchoresis - provided the quies for the practice of a 'quieti mentis'.

Earlier in his letter to the novice monk Lanzo, Anselm compared monastic life to a port which offered '... shelter from the storms and tossings of the world', and cautioned him to be wary of 'disturbing the tranquility of port with the wind of fickleness and the hurricane of impatience, and [to] let his mind, lying at rest ("quieta") under the protection of constancy and forbearance, give itself up to the fear and love of God in carefulness and sweet delight'. ${ }^{8}$ Monasticism offered a tranquil haven for the mind away from the noise of the storm and squalls of secular life. Yet despite the safe berth, the novice monk must still beware the unsettling winds of emotion that threatened his mental stillness.

In withdrawing to the desert, the early monks not only relinquished the shackles of secular life but removed themselves from all associations with their previous lives. Their goal, theôria in the Greek and contemplatio in Latin, was to attain knowledge of God, a state of grace unattainable to those still enmeshed in the vices or passiones. Before the monk could hope to produce the purity of prayer that would bring him close to God, a state of apatheia, freedom from the passions, had to be attained. John Cassian writing in the 420 s gave the following advice:

First, anxiety about fleshly matters should be completely cut off. Then, not only the concern for but in fact even the memory of affairs and business should be refused all entry whatsoever; detraction, idle speech, talkativeness, and buffoonery should also be done away with; the disturbance of anger, in particular, and of sadness should be entirely torn out; and the harmful shoot of fleshly lust and of avarice should be uprooted. (9.III.1) ${ }^{9}$

After the cleansing purgation, the 'unshakeable foundations of deep humility should be laid', upon which a tower of spiritual virtues 'that will penetrate the heavens' can be 'immovably fixed'. Cassian then employed an analogy, perhaps the inspiration for Anselm some 700 years later, in 
which he explained that the tower, 'resting on such foundations, even though the heaviest rains of the passions should beat against it like a battering ram and a savage tempest of adversary spirits should rush upon it, will not only not fall into ruin but no force of any kind will ever disturb it' (9.II.3-4). The mind, housed in its tower founded on deep humility, can withstand the destabilising threat posed by the passions.

Thus the goal of the monk was mental tranquility, to remain unperturbed or unmoved by thoughts arising from the secular world. John of Lycopolis maintained that '... through any sinful act or onset of perverse desire the devil enters into our hearts... [and] such hearts can never have peace or stillness ("quietem")'. ${ }^{10}$ In order to eliminate one's inclination towards sinful acts, the monk submitted himself to self-abnegating or ascetic practices. Abstinence from sex, food and drink, company and conversation, clothing and even the sight of the outside world was intended to subdue bodily urges while rounds of prayer, psalmody and repetitive manual tasks such as 'basket-making' or weaving allowed the mind to meditate continuously on God. By withdrawing into oneself through such ascetic practices, the monk might achieve a state known to the Greek-speaking desert dwellers as hesychasm ('stillness, rest, quiet, silence') in which the monk, through unceasing wordless prayer, might receive experiential knowledge of God. St Antony, the first of the great Egyptian hermits, wrote that revelations came only to a 'calm' soul. ${ }^{11}$ Hesychasm, transmitted to the Latin West as theôria or contemplatio and achievable only through a quies mentis ('stillness of mind'), brought a heightened relationship with God.

A mind 'at rest' or 'stilled', however, was not easily achieved. If we recall Anselm's directive, it was a task to which the monk ought to devote his 'whole strength'. Moreover, everything in his letter, he claimed, 'pertained to the preservation of a stilled mind ("ad custodiendam mentis quietem")'. ${ }^{12}$ Stilled minds need to be maintained and defended; upkeep and observation were required. In other words, being 'at rest' took effort; it was something that a monk worked hard to achieve. ${ }^{\text {iii }}$ Acquiring and maintaining a stilled mind was a difficult task, a fact which the Desert Fathers acknowledged. In John Cassian's Conferences, a set of twenty-four thematic dialogues which codified the advice he and his friend Germanus had received from monastic elders on their visit to the Egyptian desert, he returned repeatedly to the topic of restless or wandering thoughts.

iii Cf. Chap. 9. 
He complained at the way his mind inevitably strayed during his spiritual exercises:

My mind is infected by poetry, those silly stories of fable-tellers [like Ovid] and the tales of war in which I was steeped from the beginning of my basic studies when I was very young.... When I am singing the psalms or else begging pardon for my sins, the shameful memory of poems slip in or the image of warring heroes turns up before my eyes. Daydreaming about such images constantly mocks me and to such an extent that it prevents my mind from attaining to higher insights and cannot be driven away by daily weeping. (14.XII)

Elsewhere he spoke of 'careless and slippery digressions of thought... which prick the mind with their vague and subtle suggestiveness' $(23$. VII.1,5). In another Conference, he has Germanus describe how the mind 'wanders off in slippery streams' ('lubricus discursibus animus evagatur') and bewail the fact that even when the mind is restored to the fear of God or spiritual contemplation:

... before it can be fixed there, it disappears again still more swiftly. And when we apprehend, as though awakened, that it has strayed ('deviasse') from its proposed intention ... we wish to bind it with the most tenacious attentiveness of heart as though in chains, [but] in the midst of our attempts, [it] slips away, swifter than an eel from the recesses of the mind. (7.III.4)

Even when the heart is willing, it seems the mind often refuses to be stilled. But the monk should not lose hope. Cassian's complaints were met with sage advice, for although 'wandering thoughts' ('cogitationum pervagatione'), glossed as 'every thought that is not only wicked but even idle and that to some extent departs from God', were 'the most impure fornication' (14.XI.5), they were part of the human condition. In the penultimate Conference, Abba Theonas poses the question:

Who can continually maintain such a fervour of spirit that he does not sometimes when slippery thoughts ('lubricis cogitationibus') take his attention away from prayer sometimes plunge from heavenly to earthly realities? ... Who has never been worried about food, clothing or concerned about welcoming brothers ... or building a cell? ... No one apart from our Lord and Saviour has so stilled ('defixa') the natural vagaries of his mind ('naturalem pervagationem mentis') and remained in constant contemplation of God 
that he has never been snatched away from it and sinned for love of some earthly thing. (23.VIII.2)

In a Christian adaptation of Neoplatonist notions of the soul, the human mind in the human body cannot help but wander. Since Adam and Eve's disobedience in the Garden of Eden, wandering thoughts were an inescapable fact of life, and even monks ascending to the height of spiritual theôria were not impervious to wandering and restless thoughts.

If one's thoughts had to wander, the answer lay in letting them stray on to spiritual matters. This was the advice John Cassian received from Abba Nesteros: let readings and meditations upon spiritual writings replace the fables and narratives of youth, store this knowledge deep in the recesses of your mind so that 'not only every aim and meditation of your heart but also every wandering and digressive thought of yours will become a holy and continuous reflection on the divine law' (14.XIII.7). In a celebrated passage Cassian compared the human heart and mind to millstones:

... which the swift rush of the waters turns with a violent revolving motion. As long as the waters' force keeps them spinning they are utterly incapable of stopping their work, but it is in the power of the one who supervises to decide whether to grind wheat or barley or darnel.... In the same way the mind cannot be free from agitating thoughts during the trials of the present life, since it is spinning around in the torrents of the trials that overwhelm it from all sides. But whether these will be either refused or admitted into itself will be the result of its own zeal and diligence. For if...we constantly return to meditating on Holy Scripture, ... to the desire for perfection and hope of future blessedness, it is inevitable that... the mind [will] dwell on the things that we have been meditating on. But if we are overcome by laziness and negligence and... get involved in worldly concerns and unnecessary preoccupations, the result will be as if a kind of weed has sprung up, which will impose harmful labour on our heart. (1.XVIII.1-2)

The solution to the seemingly paradoxical quest for quies mentis, 'a stillness of mind', lay in reading, preparing and habituating one's mind so that during its wanderings it would automatically alight on spiritual matters rather than those slippery itchings which would send the monk into sin. In short, the mind cannot be stilled but the heart need not move.

In the Christian monastic tradition, attaining a quiet mind or mental rest, a state in which the mind was no longer troubled by distracting thoughts, was a ceaseless endeavour, which required an unstinting 
attentiveness to the contents of consciousness. It was also unrealizable. In this respect, there is overlap with contemporary cognitive science to the extent that wandering thoughts are considered an inescapable feature of human experience: the mind is always working and whirring around. Yet where the medieval and the modern do part company is in the way rest is defined in the context of mental tasks. In the domain of the neuroscientific experiment, the 'resting state' is conceptualized as being 'off task'. Participants in neuroimaging studies of the DMN are intentionally not directed to perform mental tasks. Mental rest - the 'resting state' - is thus defined by the absence of a task. In the world of the Egyptian desert or medieval cloister, however, we find the entirely opposite view: mental rest was not only a task but one requiring sustained effort.

\section{Notes}

1. St. Anselm, The Letters of Saint Anselm of Canterbury. Cistercian Studies Series, 3 Vols, ed. Walter Fröhlich, vol. I (Kalamazoo, Mich.: Cistercian Publications, 1990), 133-37.

2. Eadmer of Canterbury, The Life of Saint Anselm, Archbishop of Canterbury, ed. Richard William Southern (Oxford: Oxford University Press, 1962), $32-34$.

3. Jonathan Smallwood and Jonathan W. Schooler, 'The Restless Mind', Psychological Bulletin 132, no. 6 (2006): 956.

4. Jonathan Smallwood and Jonathan W. Schooler, 'The Science of Mind Wandering: Empirically Navigating the Stream of Consciousness', Annual Review of Psychology 66 (2015): 487-518.

5. Charlton T. Lewis and Charles Short, A Latin Dictionary (Oxford: Oxford University Press, 1879).

6. 'Vitae patrum', Patrologia Latina 73, 858A-860C, 1849.

7. Rufinus, 'Historia monachorum in Ægypto', in Patrologia Latina 21, $858 \mathrm{~A}-860 \mathrm{C}, 1849$.

8. Eadmer of Canterbury, The Life of Saint Anselm, Archbishop of Canterbury, 34.

9. John Cassian, The Conferences. Ancient Christian Writers 57, trans. Boniface Ramsey O.P. (New York/Mahwah, N.J.: Newman Press, 1997), in text citation by conference, chapter and sub-chapter. The Latin text is printed in Patrologia Latina 49, 477-1328.

10. Rufinus, 'Historia monachorum in Ægypto', 396C.

11. David Brakke, Athanasius and Asceticism (Baltimore, Md.: Johns Hopkins University Press, 1998), 239.

12. Eadmer of Canterbury, The Life of Saint Anselm, Archbishop of Canterbury, 34. 


\section{FURTHER READING}

Carruthers, Mary J. The Craft of Thought: Meditation, Rhetoric, and the Making of Images, 400-1200. Cambridge: Cambridge University Press, 1998.

Dunn, Marilyn. The Emergence of Monasticism: From the Desert Fathers to the Early Middle Ages. Oxford: Blackwell Publishers, 2000.

Russell, Norman, and Benedicta Ward, S.L.G. The Lives of the Desert Fathers. London: Cistercian Publications, 1981.

Ward, Benedicta, S.L.G. The Desert Fathers: Sayings of the Early Christian Monks. London: Penguin Books, 2003.

White, Carolinne. Early Christian Lives: Life of Antony by Athanasius, Life of Paul of Thebes by Jerome, Life of Hilarion by Jerome, Life of Malchus by Jerome, Life of Martin of Tours by Sulpicius Severus, Life of Benedict by Gregory the Great. London: Penguin Books, 1998.

Hilary Powell is a medievalist at Durham University (Department of English Studies and Centre for Medical Humanities). She is currently researching how the experience of letting one's mind wander possessed both positive and negative associations in the medieval monastic tradition.

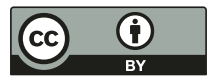

This chapter is distributed under the terms of the Creative Commons Attribution 4.0 International License (http://creativecommons.org/ licenses/by/4.0/), which permits use, duplication, adaptation, distribution and reproduction in any medium or format, as long as you give appropriate credit to the original author(s) and the source, a link is provided to the Creative Commons license and any changes made are indicated.

The images or other third party material in this chapter are included in the work's Creative Commons license, unless indicated otherwise in the credit line; if such material is not included in the work's Creative Commons license and the respective action is not permitted by statutory regulation, users will need to obtain permission from the license holder to duplicate, adapt or reproduce the material. 